$\begin{gathered}\text { Науковий вісник Нлту України } \\ \text { Scientific Bulletin of UNFU } \\ \text { https://nv.nltu.edu.ua }\end{gathered}$
$\begin{aligned} & \text { https://doi.org/10.36930/40300308 } \\ & \text { Article received 29.04.2020 p. } \\ & \text { Article accepted 04.06.2020 p. } \\ & \text { UDC 634.51:581.63[485:477] 1994-7836 (print) }\end{aligned}$

О. М. Абоімова

Наиіональний ботанічний сад ім. М. М. Гриика НАН Украӥни, м. Київ, Украӥна

\title{
ЯВИЩЕ ДИХОГАМІЇ ТА ПРОДУКТИВНІСТЬ ПРЕДСТАВНИКІВ РОДУ JUGLANS L. В УМОВАХ КИЇВСЬКОГО ПОЛІССЯ
}

Досліджено явище дихогамії видів роду Juglans L. в колекції Національного ботанічного саду ім. М. М. Гришка НАН України (НБС) (у відділі дендрології та акліматизації плодових рослин) та у лісових насадженнях Голосієва, що у Києві. Дослідження явища дихогамії представників роду Juglans здійснено за загальноприйнятими методиками. Урожайність визначено за методикою В. Г. Каппера (Kapper, 1930), життєздатність дерев - за методикою Л. С. Савєльєвої. Статистичне оброблення отриманих даних виконано за рекомендаціями Г. М. Зайцева. Встановлено, що за типом дихогамії рослини розподіляються у насадженнях так: протандричні дерева - 45,9\%; протогінічні дерева - 50,7 \%, виявлено також $2,6 \%$ гомогамних дерев. Рослини $J$. microcarpa та J. major представлені у колекційних насадженнях НБС поодинокими екземплярами. За період здійснення досліджень періодичності плодоношення та цвітіння видів роду Juglans не виявлено, урожай щорічний. Термін достигання плодів у рослин роду Juglans тривав найдовше у представників з Ірано-Туранської флористичної області (J. regia) - $127^{ \pm 8,3}$ доби. Найкоротший період розвитку плодів зафіксовано у рослин 3 ЯпоноКитайської флористичної області (J. mandshurica) - 88 $\pm 6,4$ доби. Аналізуючи отримані дані 3 вивчення дихогамії представників роду Juglans в умовах Київського Полісся, встановлено, що показники розвитку дерев (висота, товщина стовбура, життєздатність) з різним типом дихогамії (протандричний, протогінічний, гомогамний) у межах видів, різновидів та форм майже не відрізняються. Проте статистично підтверджено різницю показників урожайності та маси плодів у всіх дослідних видів з різним типом дихогамії. Так, зафіксовано вищий бал урожайності гомогамних дерев; - найвищий цей показник у рослин J. regia $\left(5,9^{ \pm 0,65}\right)$. Показники урожайності нижчі у рослин 3 протоандричним типом дихогамії. Найнижчий цей показник у рослин J.ailantifolia $\left(4,7^{ \pm 0,51}\right)$. Маса плоду більша у протоандричних дерев. Найбільший цей показник у рослин $J$. regia $\left(14,5^{ \pm 0,22}\right)$. Меншу масу плоду зафіксовано у рослин 3 гомогамним типом дихогамії. Найменший цей показник у рослин J. regia L. f. fertillis $\left(10,1^{ \pm 0,54}\right)$. Виявлено корелятивну залежність між продуктивністю дерев і показниками габітусу. Кореляцію між показниками висоти дерев, товщини стовбура, життєздатністю і типом дихогамії не виявлено.

Ключові слова: протандрія; протогінія; гомогамія; урожайність.

\section{Вступ}

На думку вчених $[4,7,8]$, тип дихогамії - спадкова, еволюційно закріплена ознака, зумовлена певними генами. Явище дихогамії сприяє перехресному запиленню, яке полягає в тому, що тичинки і маточки квіток одного виду рослин дозрівають неодночасно. На одних примірниках раніше розкриваються пиляки, а маточки затримуються в розвитку, на інших, навпаки, дозріває раніше маточка, а відстають у розвитку пиляки.

Рослинам роду Juglans властиві три типи дихогамії: коли на одному і тому самому дереві спочатку цвітуть маточкові квітки, а потім тичинкові (тип цвітіння протогінічний); або першими цвітуть тичинкові квітки, а потім маточкові, такі дерева називають протандричними. Дуже рідко трапляються дерева, у яких збігаються цвітіння маточкових і тичинкових квіток (гомогамний тип цвітіння) $[5,7,8]$.

Для дослідження було використано рослини роду Juglans L. (віком від 55 до 65 років) у колекції Національного ботанічного саду ім. М. М. Гришка НАН Ук- раїни (НБС) (у відділі дендрології та акліматизації плодових рослин) та у лісових насадженнях Голосієва у Києві. Назви рослин наведено за електронним ресурсом The Plant List (2019) $з$ доповненнями за World Plant (North america's largest database, 2019). Тепер колекція, створення якої розпочато з 1949 р., складається із семи видів, одного різновиду і однієї форми, природні ареали яких належать до чотирьох флористичних областей: Атлантико-Північноамериканської - J. cinerea L., J. nig$r a$ L., Мадреанської - J. major (Torr.) A. Heller, J. microcarpa Berland. (у колекцію НБС рослини завезені під назвою, яку тепер вважають синонімом - J. rupestris Engelm. ex Torr.), Східноазійської (Японо-Китайської) J. ailantifolia Carriere (у колекцію НБС рослини завезені під назвою, яку тепер вважають синонімом - J. sieboldiana Maxim.); J. ailantifolia var. cordiformis (Makino) Rehder (у колекцію НБС рослини завезені під назвою, яку тепер вважають синонімом - J. cordiformis Maxim., у літературі поширений й інший синонім - J. subcordiformis Dode), J. mandshurica Maxim.; Ірано-Туранської - J. re-

Інформація про автора:

Абоімова Олександра Миколаївна, аспірант, пров. інженер, відділ акліматизації плодових рослин. Email: aboimovaaleksandra@gmail.com; https://orcid.org/0000-0002-3622-4669

Цитування за ДСтУ: Абоімова О. М. Явище дихогамії та продуктивність представників роду Juglans L. в умовах Київського Полісся. Науковий вісник НЛтУ України. 2020, т. 30, № 3. С. 47-50.

Citation APA: Aboimova, O. M. (2020). The phenomenon of dichogamy and the productivity of the species of the genus Juglans L. in conditions of Kyiv Polissya. Scientific Bulletin of UNFU, 30(3), 47-50. https://doi.org/10.36930/40300308 
gia L. (типові рослини та окрема колекція рослин скороплідної форми - J. regia f. fertillis Petz et Kirch.).

Об'єкт дослідження - дихогамія та продуктивність представників роду Juglans L.

Предмет дослідження - методи і засоби встановлення явища дихогамії представників роду Juglans в умовах Київського Полісся, що дасть змогу здійснити пошук корелятивних зв'язків між типом дихогамії та розвитком рослин, урожайністю і масою плодів.

Мета дослідження зводиться до аналізу явища дихогамії представників роду Juglans в умовах Київського Полісся; виявлення корелятивної залежності між продуктивністю дерев та показниками габітусу; визначенні термінів достигання плодів рослин роду Juglans від початку росту зав'язі.

Завдання дослідження: здійснити аналіз літературних джерел, викласти методику, основний матеріал та результати дослідження, проаналізувати результати дослідження та зробити відповідні висновки.

Наукова новизна дослідження полягає у тому, що було вперше розроблено методику визначення дихогамії представників роду Juglans, яка полягає у пошуку корелятивних зв'язків між типом дихогамії та розвитком рослин; урожайністю і масою плодів, що має як теоретичне, так і практичне значення для відбору перспективних видів і форм.

Практична значущість отриманих результатів дослідження полягає у тому, що дослідження явища дихогамії представників роду Juglans здійснено за загальноприйнятими методиками, а урожайність визначено за методикою В. Г. Каппера, життєздатність дерев - за методикою Л. С. Савєльєвої.

Аналіз літературних джерел 3 дослідження дихогамії представників роду Juglans показав, що вони мають фрагментарний характер і стосуються переважно рослин $J$. regia. За даними літературних джерел встановлено, що на одному і тому самому дереві в окремі роки утворюються тільки тичинкові або тільки маточкові квітки, а затяжні зими сприяють одночасному зац- вітанню тичинкових і маточкових суцвіть у протандричних форм [8]. Тому завданням наших досліджень $є$ вивчення дихогамії видів роду Juglans в умовах інтродукції та її вплив на показники розвитку й урожайності цих рослин.

Матеріали і методи досліджсення. Дослідження явища дихогамії представників роду Juglans виконано за загальноприйнятими методиками. Урожайність визначали за методикою В. Г. Каппера [1]; життєздатність дерев - за методикою Л. С. Савельєвої [6]; статистичне оброблення отриманих даних виконували за рекомендаціями Г. М. Зайцева [10].

\section{Результати дослідження та їх обговорення}

За період досліджень (2015-2019 рр.) у представників роду Juglans утворювались і чоловічі, і жіночі квітки. Періодичності в цвітінні, зміни типів дихогамії дослідних рослин не виявлено.

Дослідженнями встановлено, що розподіл протандричних і протогінічних дерев у насадженнях майже однаковий і становить близько $50 \%$ кожного типу від їх загальної кількості, що підтверджує літературні дані $[8,9]$. У лісових насадженнях Голосієва та колекції ботанічного саду НАН України ім. М. М. Гришка всього обстежено 214 дерев: середній вибірковий показник рослин кожного виду становив по 30 дерев; 3 них виявилось 112 протандричних дерев (45,9\%) та 137 протогінічних дерев $(50,7 \%)$, виявлено також 7 гомогамних дерев $(2,6 \%)$. Рослини J. microcarpa та J. major представлені у колекційних насадженнях НБС поодинокими екземплярами (табл. 1).

Під час обстеження дерев з різним типом дихогамії визначали їх висоту, товщину стовбура та життєздатність. Згідно з даними табл. 2, показники розвитку дерев (висота, товщина стовбура, життєздатність) 3 різним типом дихогамії (протандричний, протогінічний, гомогамний) у межах видів відрізняються не істотно і не залежать від типу дихогамії.

Табл. 1. Розподіл дерев видів роду Juglans за типом дихогамії

\begin{tabular}{|c|c|c|c|c|}
\hline \multirow{2}{*}{ Вид, форма } & \multirow{2}{*}{ Обстежено дерев } & \multicolumn{3}{|c|}{ Тип дихогамії } \\
\cline { 3 - 5 } & & Протандрія, шт. (\%) & Протогінія, шт. (\%) & Гомогамія, шт. (\%) \\
\hline J. regia L. & 30 & $13(43)$ & $15(50)$ & $2(6,7)$ \\
\hline J. regiaf. fertillis & 30 & $14(46)$ & $14(46)$ & $2(6,7)$ \\
\hline J.cinerea & 30 & $12(40)$ & $16(53)$ & $2(6,7)$ \\
\hline J. nigra & 30 & $17(56)$ & $13(43)$ & не виявлено \\
\hline J. major & 2 & $2(100)$ & не виявлено & не виявлено \\
\hline J. microcarpa & 2 & $2(100)$ & не виявлено & не виявлено \\
\hline J.ailantifolia var. cordiformis & 30 & $14(46)$ & $15(50)$ & $1(3,3)$ \\
\hline J.ailantifolia & 30 & $13(43)$ & $17(56)$ & не виявлено \\
\hline J.mandshurica & 30 & $14(46)$ & $16(53)$ & не виявлено \\
\hline
\end{tabular}

Табл. 2. Розвиток рослин Juglans залежно від типу дихогамії

\begin{tabular}{|c|c|c|c|c|c|c|c|c|c|}
\hline \multirow{2}{*}{ Вид, форма } & \multicolumn{3}{|c|}{ Висота дерев, м } & \multicolumn{3}{|c|}{ Товщина стовбура, см } & \multicolumn{3}{|c|}{ Життєздатність, бал } \\
\hline & $q^{*}$ & $\hat{\sigma}$ & ㅇ, $\hat{O}^{-1}$ & q & $\hat{\sigma}$ & q, $0^{\wedge}$ & q & $\hat{0}$ & $9,0^{\wedge}$ \\
\hline J. regia L. & $10,3^{ \pm 0,21}$ & $10,0^{ \pm 0,22}$ & $10,2^{ \pm 0,66}$ & $50,4^{ \pm 0,22}$ & $50,0^{ \pm 0,41}$ & $50,2^{ \pm 0,32}$ & $5,4^{ \pm 0,56}$ & $5,3^{ \pm 0,70}$ & $5,6^{ \pm 0,71}$ \\
\hline J. regiaf.fertillis & $7,0^{ \pm 0,34}$ & $7,3^{ \pm 0,67}$ & $7,7^{ \pm 0,68}$ & $30,1^{ \pm 0,61}$ & $30,2^{ \pm 0,55}$ & $30,3^{ \pm 0,41}$ & $4,9^{ \pm 0,56}$ & $4,7^{ \pm 0,68}$ & $4,8^{ \pm 0,66}$ \\
\hline J.cinerea & $9,7^{ \pm 0,65}$ & $9,2^{ \pm 0,81}$ & $9,4^{ \pm 0,81}$ & $59,1^{ \pm 0,54}$ & $60,0^{ \pm 0,68}$ & $59,4^{ \pm 0,45}$ & $5,4^{ \pm 0,28}$ & $5,2^{ \pm 0,64}$ & $5,3^{ \pm 0,71}$ \\
\hline J. nigra & $12,1^{ \pm 0,41}$ & $12,7^{ \pm 0,77}$ & не виявлено & $61,1^{ \pm 0,42}$ & $60,6^{ \pm 0,76}$ & не виявлено & $6,0^{ \pm 0,1}$ & $6,0^{ \pm 0,1}$ & не виявлено \\
\hline J. major & не виявлено & $9,7^{ \pm 0,23}$ & не виявлено & не виявлено & $52,2^{ \pm 0,41}$ & не виявлено & не виявлено & $5,2^{ \pm 0,34}$ & не виявлено \\
\hline J. microcarpa & не виявлено & $8,4^{ \pm 0,42}$ & не виявлено & не виявлено & $49,4^{ \pm 0,22}$ & не виявлено & не виявлено & $4,9^{ \pm 0,67}$ & не виявлено \\
\hline $\begin{array}{l}\text { J.ailantifolia var. } \\
\text { cordiformis }\end{array}$ & $10,4^{ \pm 0,32}$ & $10,2^{ \pm 0,56}$ & $10,5^{ \pm 0,21}$ & $46,1^{ \pm 0,21}$ & $46,3^{ \pm 0,16}$ & $46,8^{ \pm 0,67}$ & $5,0^{ \pm 0,6}$ & $5,1^{ \pm 0,70}$ & $5,3^{ \pm 0,67}$ \\
\hline J.ailantifolia & $11,1^{ \pm 0,44}$ & $11,5^{ \pm 0,13}$ & не виявлено & $48,4^{ \pm 0,63}$ & $49,2^{ \pm 0,24}$ & не виявлено & $4,7^{ \pm 0,56}$ & $4,3^{ \pm 0,68}$ & не виявлено \\
\hline J.mandshurica & $9,6^{ \pm 0,31}$ & $9,3^{ \pm 0,21}$ & не виявлено & $44,2^{ \pm 0,24}$ & $44,4^{ \pm 0,12}$ & не виявлено & $5,4^{ \pm 0,34}$ & $5,2^{ \pm 0,66}$ & не виявлено \\
\hline
\end{tabular}

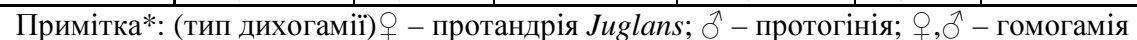


Табл. 3. Урожайність і маса плодів дерев з різним типом дихогамії

\begin{tabular}{|c|c|c|c|c|c|c|}
\hline \multirow{2}{*}{ Вид } & \multicolumn{2}{|c|}{ Урожайність, бал; тип дихогамії } & \multicolumn{2}{c|}{ Масса плодів, г; тип дихогамії } \\
\cline { 2 - 6 } & Протанд. & Протогін. & Гомогам. & Протанд. & Протогін. & Гомогам. \\
\hline J. regia & $5,1^{ \pm 0,22}$ & $5,4^{ \pm 0,53}$ & $5,9^{ \pm 0,65}$ & $14,5^{ \pm 0,22}$ & $14,0^{ \pm 0,41}$ & $13,1^{ \pm 0,51}$ \\
\hline J. regiaf. fertillis & $4,8^{ \pm 0,37}$ & $5,7^{ \pm 0,31}$ & $5,8^{ \pm 0,43}$ & $11,5^{ \pm 0,31}$ & $10,0^{ \pm 0,31}$ & $10,1^{ \pm 0,54}$ \\
\hline J.cinerea & $5,2^{ \pm 0,42}$ & $5,9^{ \pm 0,12}$ & $5,4^{ \pm 0,52}$ & $12,4^{ \pm 0,21}$ & $11,1^{ \pm 0,25}$ & $10,2^{ \pm 0,25}$ \\
\hline J. nigra & $5,8^{ \pm 0,12}$ & $6,0^{ \pm 0,42}$ & не виявлено & $13,6^{ \pm 0,16}$ & $12,2^{ \pm 0,18}$ & не виявлено \\
\hline J. major & $5,7^{ \pm 0,44}$ & не виявлено & не виявлено & $11,1^{ \pm 0,24}$ & не виявлено & не виявлено \\
\hline J. microcarpa & $5,6^{ \pm 0,61}$ & не виявлено & не виявлено & $10,4^{ \pm 0,13}$ & не виявлено & не виявлено \\
\hline J.ailantifolia var. cordiformis & $5,4^{ \pm 0,65}$ & $5,9^{ \pm 0,57}$ & $5,6^{ \pm 0,46}$ & $14,1^{ \pm 0,52}$ & $13,0^{ \pm 0,71}$ & $13,1^{ \pm 0,61}$ \\
\hline J.ailantifolia & $4,7^{ \pm 0,51}$ & $4,9^{ \pm 0,65}$ & не виявлено & $14,4^{ \pm 0,31}$ & $13,0^{ \pm 0,13}$ & не виявлено \\
\hline J.mandshurica & $5,3^{ \pm 0,46}$ & $6,0^{ \pm 0,28}$ & не виявлено & $13,1^{ \pm 0,23}$ & $12,0^{ \pm 0,44}$ & не виявлено \\
\hline
\end{tabular}

Встановлено, що за період проведення досліджень періодичності плодоношення видів роду Juglans не виявлено. Загалом термін достигання плодів у рослин роду Juglans тривав найдовше у представників з Ірано-Туранської флористичної області (J. regia) $-127^{ \pm 8,3}$ доби. Найкоротший період розвитку плодів зафіксовано у рослин 3 Японо-Китайської флористичної області $(J$. mandshurica) $-88^{ \pm 6,4}$ доби (рисунок).

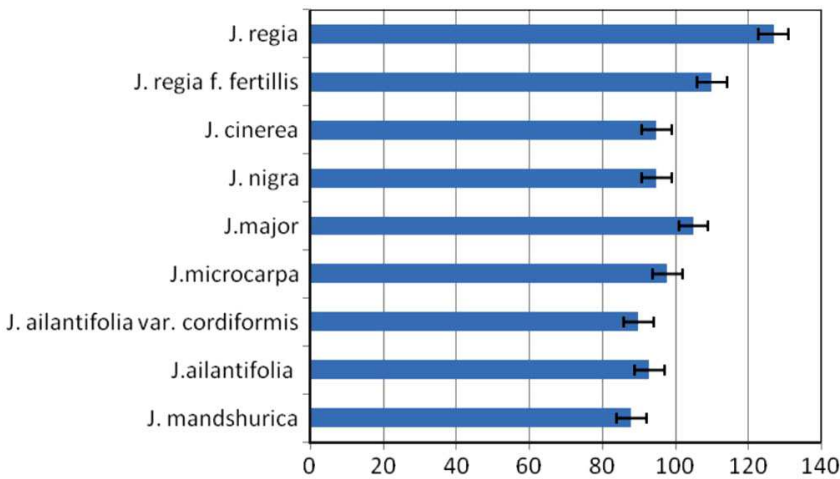

Рисунок. Тривалість достигання плодів рослин роду Juglans від початку росту зав'язі

Під час дослідження урожайності та маси плодів дослідних рослин залежно від типів дихогамії статистично підтверджено різницю показників урожайності та маси плодів рослин Juglans 3 різним типом дихогамії. Так, зафіксовано вищий бал урожайності гомогамних дерев дослідних видів; - найвищий цей показник у рослин $J$. regia $\left(5,9^{ \pm 0,65}\right)$. Показники урожайності нижчі у рослин $з$ протандричним типом дихогамії. Найнижчий цей показник у рослин J.ailantifolia $\left(4,7^{ \pm 0,51}\right)$. Маса плоду більша у протандричних дерев. Найбільший цей показник у рослин $J$. regia $\left(14,5^{ \pm 0,22}\right)$. Меншу масу плоду зафіксовано у рослин з гомогамним типом дихогамії. Найменший цей показник у рослин J. regia L. f. fertillis $\left(10,1^{ \pm 0,54}\right)$.

Табл. 4. Габітус та продуктивність видів роду Juglans

\begin{tabular}{|l|c|c|}
\hline $\begin{array}{c}\text { Вид, різновид, } \\
\text { форма }\end{array}$ & $\begin{array}{c}\text { Діаметр } \\
\text { крони, м }\end{array}$ & $\begin{array}{c}\text { Продуктивність у пере- } \\
\text { рахунку на кількість } \\
\text { плодів, шт. (3 1-го дерева) }\end{array}$ \\
\hline J. regia & $9,1^{ \pm 3,3}$ & $3825-4250$ \\
\hline J. regiaf. fertillis & $3,9^{ \pm 4,5}$ & $900-1800$ \\
\hline J. cinerea & $11,3^{ \pm 6,1}$ & $1275-1700$ \\
\hline J. nigra & $12,2^{ \pm 4,4}$ & $4500-5850$ \\
\hline J.major & $11,1^{ \pm 3,6}$ & $2000-2500$ \\
\hline J.microcarpa & $10,2^{ \pm 3,2}$ & $1800-2400$ \\
\hline J.ailantifolia var. cordiformis & $8,9^{ \pm 4,5}$ & $1500-2000$ \\
\hline J. ailantifolia & $8,7^{ \pm 3,7}$ & $1000-1500$ \\
\hline J. mandshurica & $9,9^{ \pm 3,3}$ & $1500-2000$ \\
\hline
\end{tabular}

Вивчення продуктивності (кількість плодів (шт.) 3 одного дерева), проведених у 2015-2019 рр. видів роду Juglans (середній вибірковий показник рослин кожного виду Juglans без урахування типу дихогамії), виявило залежність цього показника від видових особливостей (габітусу) рослин (табл. 4).

Встановлено, що діаметр крони $\left(3,9^{ \pm 4,5}\right)$ колекційних насаджень J. regia L. f. fertillis найменший; продуктивність рослин цього виду - 900-1800 шт. - найменший показник. Найбільший діаметр крони $\left(12,2^{ \pm 4,4}\right)$ відзначено у рослин $J$. nigra; продуктивність - 4500-5850 шт. найбільший показник.

\section{Висновки}

Під час дослідження дихогамії видів роду Juglans у Голосієвських лісових насадженнях та колекції НБС встановлено, що за типом дихогамії рослини розподіляються так: протандричні дерева - 45,9\%; протогінічні дерева $-50,7 \%$, виявлено також 2,6 \% гомогамних дерев. Рослини $J$. microcarpa та $J$. major представлені у колекційних насадженнях НБС поодинокими екземплярами.

Встановлено, що за період проведення досліджень періодичності плодоношення видів роду Juglans не виявлено. Загалом термін достигання плодів у рослин роду Juglans тривав найдовше у представників 3 Ірано-Туранської флористичної області (J. regia) $-127^{ \pm 8,3}$ доби. Найкоротший період розвитку плодів зафіксовано у рослин $з$ Японо-Китайської флористичної області (J. mandshurica) $-88^{ \pm 6,4}$ доби. Аналізуючи отримані дані 3 вивчення дихогамії представників роду Juglans в умовах Київського Полісся, встановлено, що показники розвитку дерев (висота, товщина стовбура, життєздатність) з різним типом дихогамії (протандричний, протогінічний, гомогамний) у межах видів, різновидів та форм істотно не відрізняються. Проте статистично підтверджено різницю показників урожайності та маси плодів всіх дослідних видів з різним типом дихогамії. Так, бал урожайності гомогамних дерев дослідних видів вищий; найвищий цей показник у рослин J. regia $\left(5,9^{ \pm 0,65}\right)$. Показники урожайності нижчі у рослин з протоандрічним типом дихогамії. Найнижчий цей показник у рослин J.ailantifolia $\left(4,7^{ \pm 0,51}\right)$. Маса плоду більша у протандричних дерев. Найбільший цей показник у рослин J. regia $\left(14,5^{ \pm 0,22}\right)$. Меншу масу плоду зафіксовано у рослин $з$ гомогамним типом дихогамії. Найменший цей показник у рослин $J$. regia L. $f$. fertillis $\left(10,1^{ \pm 0,54}\right)$. 3'ясовано, що тип дихогамії має корелятивний зв'язок з урожайністю і масою плодів. Кореляцію між показниками висоти дерев, товщини стовбура, життєздатністю і типом дихогамії не виявлено. Виявлено корелятивну залежність між продуктивністю дерев і показниками габітусу. Встановлено, що діаметр крони $\left(3,9^{ \pm 4,5}\right)$ колекційних насаджень J. regia L. f. fertillis найменший; продуктивність рослин цього виду - 900-1800 шт. - 
найменший показник. Найбільший діаметр крони $\left(12,2^{ \pm 4,4}\right)$ відзначено у рослин J. nigra; продуктивність 4500-5850 шт. - найбільший показник.

\section{References}

1. Kapper, V. G. (1930). On the organization of annual systematic observations of fruiting of tree species. Forest Experimental Proceedings, 108, 103-139

2. Kumar A., \& Sharma N. (2013). Protandrous - protogynous dimorphism in indigenous selections from North Western India and some exotic cultivars of Persian walnut (Juglans regia L.). Advances in Horticultural Science, 61-66

3. Kumar, A. (2016). Selection of homogamous walnut from seedling plantation in South Kashmir. Indian Journal of Plant Genetic Resources, 29(1), 59-65
4. Ponomarev, A. N., Demyanova, E. I., \& Grushvitsky, I. V. (1980). Pollination. In: Takhtadzhyan A. L. (Ed.), Zhizn rasteniy. Moscow: Prosveshcheniye, Flowering plants. Vol. 5. Part 1, 5578

5. Rikhter, A. A., \& Kolesnikov, V. A. (1985). Walnut crops. Krimizdat: Simferopol, $140 \mathrm{p}$.

6. Savelyeva, L. S. (1975). Resistance of trees and shrubs in protective forest plantations. Moscow: Timber industry, $168 \mathrm{p}$.

7. Schepotyev, F. L., et al. (1978). Walnut forest crops. Moscow: Timber industry, $256 \mathrm{p}$.

8. Schepotyev, F. L., Pavlenko, F. A., \& Richter, A. L. (1975). Nuts. Kyiv: Urozhay, 368 p.

9. Solar, A., Stampar, F., \& Snole, J. (1995). The degree of heterodichogamy of some walnut cultivars (Juglans regia L.). In: Slovenia. Acta Horticulturae, 442, 217-224

10. Zaytsev, G. N. (1991). Mathematical analysis of biological data. Monografiya. Moscow: Nauka, 184 p.

O. M. Aboimova

M. M. Gryshko National Botanical Garden, NAS Ukraine, Kyiv, Ukraine

\section{THE PHENOMENON OF DICHOGAMY AND THE PRODUCTIVITY OF THE SPECIES OF THE GENUS JUGLANS L. IN CONDITIONS OF KYIV POLISSYA}

The article deals with the phenomenon of dichogamy of plants of the genus Juglans L. (aged 55 to 65 years) in the collections of the M.M. Gryshko National Botanical Garden of the National Academy of Science of Ukraine (NBS) (Department of Dendrology and Acclimatization of Fruit Plants) and forest plantings in Kyiv. The study of the phenomenon of dichogamy members of the genus Juglans is conducted according to standard techniques. The yield was determined by the method of V.G. Kapper (1930), tree vitality - according to the method of L.S. Savelyeva (1975), statistical processing of the obtained data was performed according to the recommendations of G.M. Zaitsev (1991). It is revealed that according to the dichogamy type, plants are subdivided as follows: protandric trees to $45.9 \%$; protogenic trees of $50.7 \%$, and also $2.6 \%$ homogamy trees. Plant J. microcarpa and J. major are represented in the collection of planting NBS by single samples. During the period of studies on the periodicity of fruiting and flowering species of the genus Juglans are not found, the yield is found to be annual. The fruiting period of the Juglans plants lasted the longest for the representatives from the Iran-Turanian floristic region $(J$. regia $)-127^{ \pm 8.3}$ days. The shortest period of fruit development was recorded in plants from the Japanese-Chinese floristic region (J. mandshurica) $-88^{ \pm 6.4}$ days. Analyzing the data obtained for the study of dichogamy members of the genus Juglans in conditions of Kyiv Polissya, the authors revealed that tree indicators such as height, trunk thickness, and viability with different type of dichogamy (protandry, protogeny, homogamy) within species, varieties and forms do not differ significantly. However, we statistically confirmed the difference in the indices of yield and fruit weight in all the experimental species with different types of dichogamy. Thus, the yield of homogamy tree types mentioned is higher; the highest figure characterises plants of J. regia $\left(5.9^{ \pm 0.65}\right)$. Plants with protandrous type of dichogamy presented lower level of yields. The lowest rate is found of plants J. ailantifolia $\left(4.7^{ \pm 0.51}\right)$. Fruit weight was large in protandric trees. This figure is found to be the highest of plants of $J$. regia $\left(14.5^{ \pm 0.22}\right)$. Lower fruit weight was recorded on plants with homogamy type diagam. The lowest indicator is revealed considering plants of $J$. regia L. f. fertillis $\left(10.1^{ \pm 0.54}\right)$. To conclude, the correlation between tree productivity and habitus indices was found. The correlation between the values of tree height, thickness of trunk, its viability and type dichogamy was not detected.

Keywords: protandry; protogeny; homogamy; yield. 